\title{
A Review of the European Union Countries on Cross-border Mergers and Acquisitions Market
}

\author{
Hoang Long Pham - Petr Marek ${ }^{*}$
}

\begin{abstract}
:
It is a well-known fact that the main objective of every corporation is to generate profits and enhance its shareholders' wealth. Corporate growth may be achieved either internally (through organic growth) or externally (through mergers and acquisitions). In parallel with global trends, corporate growth is achieved by crossborder mergers and acquisitions (M\&As) that have increased dramatically in economies especially over the last few decades. It is also established that mergers and acquisitions come in waves - so far, six waves have been researched. The main aim of the presented paper is to analyse the activity of the European Union countries on the M\&As market and to describe the main motives for cross-border M\&As and how the performance of cross-merger M\&As is measured.
\end{abstract}

Key words: Cross-border Mergers and Acquisitions; Performance Measurement; Emerging Markets; Foreign Direct Investment.

JEL classification: G39.

\section{Introduction}

Increasing openness of the world economy has brought about significant increases in foreign direct investment (FDI) in both the developed and developing countries. Most of the (FDI) growth in international production over the past decades has been via cross-border mergers and acquisitions (M\&A). The fast increase in crossborder M\&As is generally driven by a combination of factors, especially by deregulation of the services' sector, liberalisation of the trade and investment systems and privatisation of the state-owned enterprises. Since the mid-1990s, worldwide cross-border mergers and acquisitions have increased rapidly. In 2000, the total net value of global cross-border M\&As has reached the level of US\$960 billion. In 2007, prior to the global financial crisis, the total net value of global cross-border M\&As has risen to the record level of US\$1,032 billion. Although

\footnotetext{
Hoang Long Pham; University of Economics, Prague, Faculty of Finance and Accounting, Department of Corporate Finance and Valuation, W. Churchill Sq. 4, 13067 Prague 3, Czech Republic, <xphah01@vse.cz>.

Petr Marek; University of Economics, Prague, Faculty of Finance and Accounting, Department of Corporate Finance and Valuation, W. Churchill Sq. 4, 13067 Prague 3, Czech Republic, <pema@vse.cz>.

The article is processed as an output of the research project under the institutional support IP100040 at the University of Economics, Prague. It is also supported by Department of Economics and Management, Unicorn College.
} 
Pham, H. L. - Marek, P.: A Review of the European Union Countries on Cross-border Mergers and Acquisitions Market.

not all the cross-border M\&As are financed through foreign direct investment, cross-border M\&As nevertheless account for a significant share of the global FDI flows (around 80\%), particularly in the industrial economies (UNCTAD, 2012). Therefore, the fast growth of cross-border M\&As has a significant impact on the magnitude and direction of the global FDI flows.

In some countries/industries, the internal strategy may be advantageous while in others it could be the external strategy. In the literature, different aspects of mergers and acquisitions have been investigated. Many studies have examined the causes and consequences of M\&As (Shleifer and Vishny, 2003; Rhodes-Kropf and Viswanathan, 2004; Harford, 2005; Gugler, Mueller and Weichselbaumer, 2012). Numerous researchers have focused on the mergers and acquisitions' efficiency (Martynova and Renneboog, 2008, Papadakis and Thanos 2010, Danbolt and Maciver, 2012). Since 2000, the process of globalisation has been observed and one of its key outcomes was the elimination of barriers among countries. Due to the declining income and consumption spending in the USA and Western Europe, companies from the developed markets started their expansion to e.g. Asia, South America, and also to Eastern Europe. At the same time, large emerging companies needed to access consumers and know-how from the USA and Europe.

As we can see from the last two waves, M\&As activities were observed not only in the United States or Western Europe, but also in the transition and emerging markets. Noticeably, for the past ten years, the group called BRIC (Brazil, Russia, India, and China) is very attractive for investors, mostly because of its exceptional economic growth, large number of customers and their excellent purchasing power. However, the above mentioned markets have also many weaknesses, such as a different culture and consumer behaviour as well as very high price sensitivity.

The European Union countries have been among important participants in this global surge of cross-border M\&As. In 2007, ahead of the financial crisis, the total value of the cross-border M\&A sales in the European Union economies reached US\$ 529 billion, accounting for 51 per cent of the world's total. However, in 2017 it was only US\$139 billion, accounting for 20 per cent of the world's total volume. In the European Union economies, France and the United Kingdom have been the most important contributors. In terms of the value of cross-border M\&A sales, in 2007 and 2017 France accounted for 5 per cent of the world's total volume and 29 per cent of the European Union's total volume, respectively. Although the 15 industrial members (joining before 2004) have been the dominant 
force in cross-border M\&As, new member states ${ }^{1}$ have experienced a slow increase in the cross-border M\&A activities and reached their peak in 2012 (UNCTAD, 2018a).

What is the composition of cross-border M\&As? What is the motivation for crossborder M\&As? How the cross-border M\&As performance is measured? This paper examines these questions by reviewing the available literature, studies and information on cross-border M\&As. The following research methods have been employed: scientific literature analysis and empirical research containing results of the quantitative research (data analysis, descriptive statistics) based on the UNCTAD database and information.

\section{Analysis of Cross-border M\&As in the European Union}

Cross-border M\&As is a representative term for any transactions in assets between two firms seated in two different countries. Therefore, cross-border M\&As can be defined as M\&As that involve the acquiring and target firm whose respective headquarters are located in different home countries. Cross-border M\&As increased significantly in the European Union economies over the second half of the 1990s.

Fig. 1 Cross-border M\&As of the European Union Economies, 1990-2017 (US\$ million)

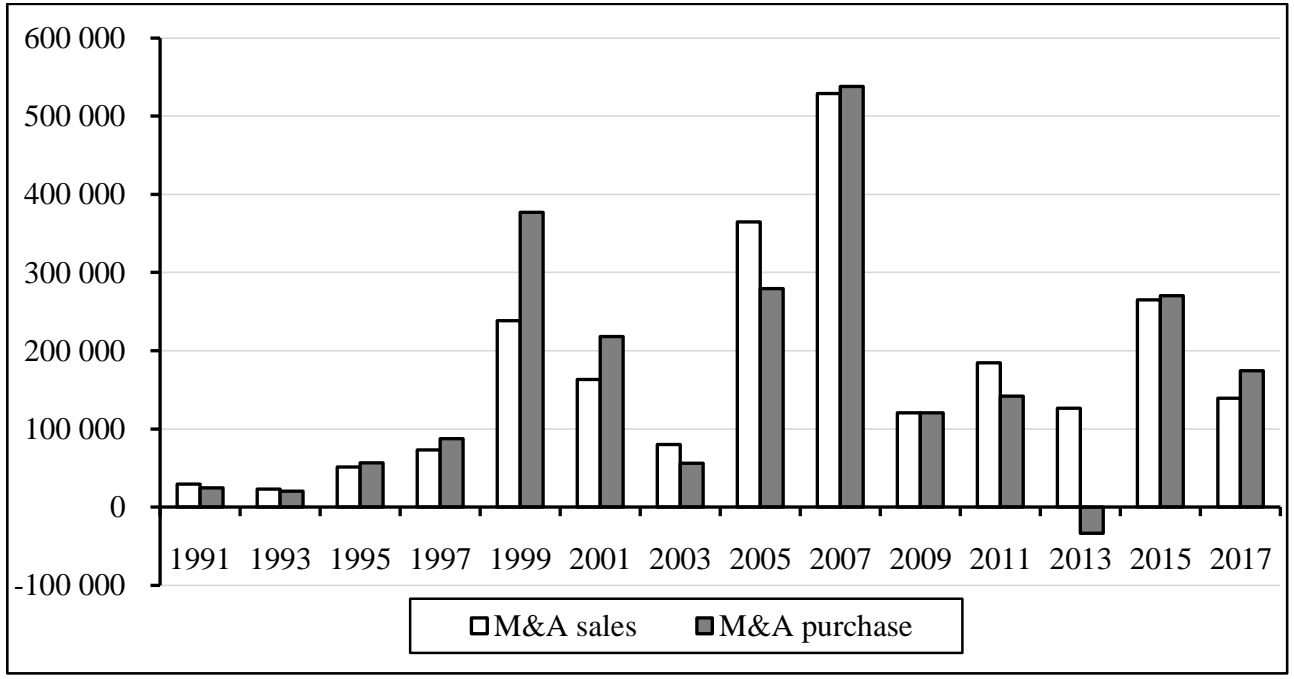

Source: UNCTAD $(2018 b, c)$.

1 The first enlargement of the European Union was in 2004, when ten states join the European Union. The new members are: Romania, Cyprus, Bulgaria, Malta, Lithuania, Estonia, Croatia, Latvia, Hungary, Slovenia, Slovakia, Czech Republic, and Poland. 
Pham, H. L. - Marek, P.: A Review of the European Union Countries on Cross-border Mergers and Acquisitions Market.

The value of the European Union cross-border M\&A sales rose from US\$ 29 billion in 1991 to US\$ 491 billion in 2000 and reached its peak in 2007 with US\$ 529 billion (before onset of the financial crisis), i.e. increasing more than 18 times. The value of cross-border purchases first rose from US\$24 billion in 1991 to US\$ 659 billion in 2000 and subsequently slightly decreased to US\$ 538 billion in 2007 (Figure 1). The European Union economies account for a large percentage of the world cross-border M\&As. From 1991 to 2010, the European Union economies accounted on average for 48 per cent of the world total value of the cross-border M\&A sales and on average for 50 per cent of the world total value of the cross-border M\&A purchases. However, from 2010 to 2017 the percentage of the world total value of the cross-border M\&A sales had decreased to 35 per cent and to 25 per cent for the cross-border M\&A purchases, respectively. The decrease was mainly due to the financial crisis and escalation of the presence of emerging markets in the cross-border M\&As market (e.g. BRIC). As the European Union is presently considered and proclaimed to be a single market, the question is whether M\&As between companies from the individual EU member states are real crossborder transactions. However, as mentioned above, we defined cross-border M\&As as M\&As that involve an acquirer firm and a target firm whose headquarters are located in different countries. Therefore, the M\&A development within the European Union from our perspective still relates to cross-border M\&As.

\subsection{Supremacy of western economies in cross-border M\&As - Former 15}

Cross-border M\&As among the European Union countries have been mainly concentrated in western/industrial economies - Former 15, which account on average for more than 95 per cent of the sales and purchase value of cross-border M\&As over the period of the past two decades. Cross-border M\&As grew very rapidly among the Former 15 economies. Cross-border M\&A sales increased from US\$ 28.8 billion in 1991 to US\$ 477 billion in 2000 and reached their peak in 2007 with US\$ 522 billion, while cross-border M\&A purchases rose from US\$ 25 billion to US\$ 531 billion over the same period (Figure 2). ${ }^{2}$

2 All values and numbers referring to cross-border M\&As are presented on the nominal and net basis. "Net cross-border M\&As are calculated considering sales of companies in a host economy to foreign multinational enterprises. It excludes sales of foreign affiliates (already owned by foreign multinational enterprises) to other foreign multinational enterprises. Divestments (sales of foreign affiliates to domestic firms) are subtracted from the value (number)." (UNCTAD, $2018 b, c)$ 
Fig. 2 Cross-border M\&As of Former 15 states, 2004-2017 (US\$ million)

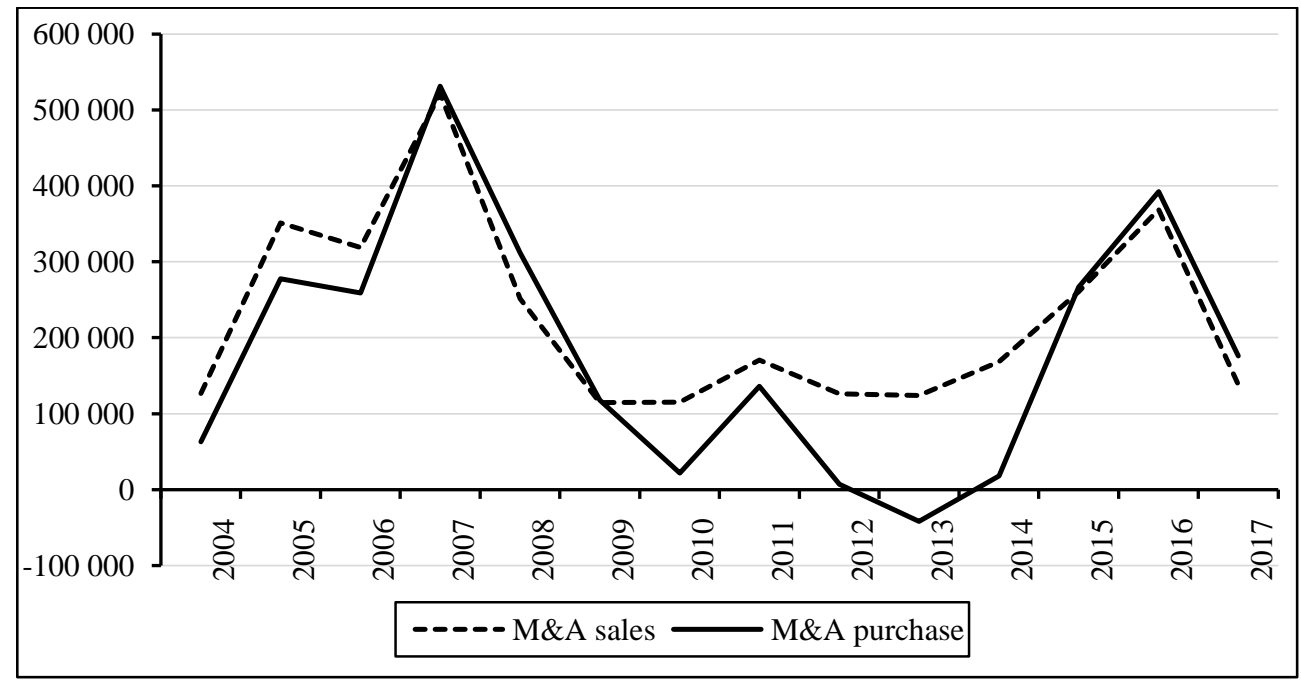

Source: UNCTAD $(2018 b, c)$.

Among the Former 15 economies, the United Kingdom has been the largest seller and purchaser among the Former 15 economies. In 2016 and 2017, the value of cross-border M\&As sales in the United Kingdom was US\$ 255 billion and US\$ 31 billion, respectively, accounting for 22 per cent of the European Union total (in 2017), while UK corporations spent US\$ 128 billion on acquiring foreign firms, accounting for 73 per cent of the European Union total (Figure 1 and Figure 2). France and Germany are second and third on the list, respectively. In 2017, the sales and purchase values of cross-border M\&As of France reached US\$17 billion and US\$ 28 billion, respectively. Over the same period, the value of cross-border M\&A sales of Germany was US\$ 19 billion, while the German corporations purchased US\$ 31 billion of foreign firms through cross-border M\&As.

\subsection{Involvement of the new member states in cross-border M\&A.}

Compared to the Former 15 economies, the new member states of the European Union have been small players in cross-border M\&As. The value of the total cross-border M\&A sales increased from US\$ 0.6 billion in 1991 to US\$ 16.3 billion in 2006, slightly decreasing in the following years only to reach US\$ 16 billion in 2011 (Figure 3). 
Pham, H. L. - Marek, P.: A Review of the European Union Countries on Cross-border Mergers and Acquisitions Market.

Fig. 3 Cross-border M\&As of the New Member Economies, 2004-2017 (US\$ million)

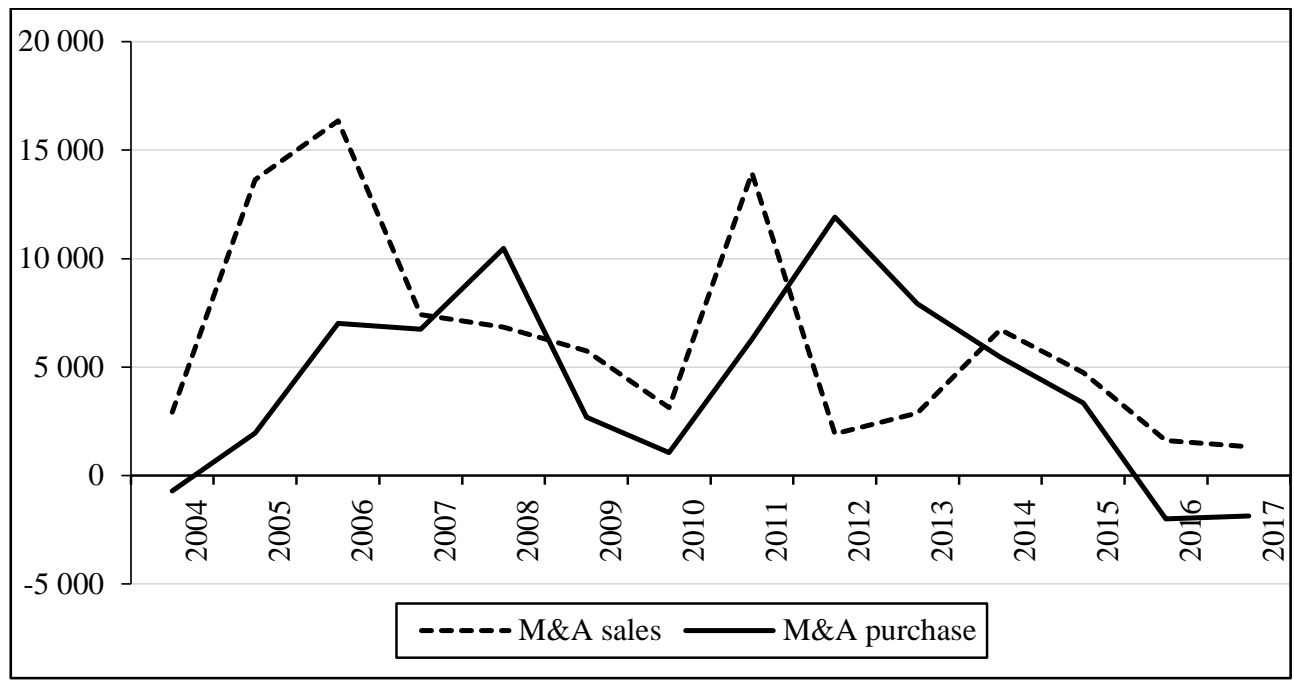

Source: UNCTAD $(2018 b, c)$.

The value of the cross-border M\&A purchases rose from US\$ 0.01 billion to US\$ 10 billion in 2008 and reached its peak of US\$ 12 billion in 2012 (Figure 1 and Figure 2). Since then, the value of the sales and purchases has a declining trend which continues until now. Increase in the cross-border M\&A purchases in the new member economies is until 2012 mainly driven by the Czech Republic, Poland and Hungary, which are the main bases of the acquiring firms. The acquisition targets are primarily firms in the neighbouring economies.

For the past 20 years, rapidly increasing has been also the trend of cross-border M\&As in the developing economies. The increase in the cross-border M\&A purchases in the developing economies is mainly driven by the BRIC group and the East and Southeast Asian economies, among which Singapore and Hong Kong are the main bases of the acquiring firms.

\section{Motivations for Cross-border M\&As}

Cross-border M\&As represent one mode of the FDI entry into foreign countries. The OLI (ownership advantage, location advantage and internalisation advantage) paradigm formulated by Dunning (2000) is the most influential explanation for the international production. It has described a new theoretical framework to analyse and explain the motives and causes of FDI through cross-border M\&As. Apart from the general explanations of the paradigm, there are some specific motivating factors for corporations choosing cross-border M\&As as means for their 
investment in foreign locations (Chen et. al., 2003). Furthermore, there continues to grow interest among scholars and practicing managers to understand the motivation for cross-border activities. This interest increases since empirical findings claim that it is difficult for M\&As to create any value for the acquiring firms' shareholders, with studies reporting both the value creation and abnormal return destruction (Aw and Chatterjee, 2004). Therefore, various studies have paid a lot of attention to understand the motives behind cross-border merger and acquisitions.

In general, three major motives of cross-border M\&As have been advanced in the literature: the synergy motive, the agency (market) motive and the diversification motive (Shleifer et al., 1992). The synergy motive suggests that M\&As occur because of economic gains of the two merging firms and the value of the postM\&A firm is greater than the sum of the individual companies' values prior to the merger. It is common to divide the synergy effect into two categories: the operating synergy and the financial synergy. According to (Chen et. al., 2003), efficiency gains can be achieved through synergies in cross-border M\&As. Synergies can be static or dynamic. Static synergies include combining the firms' resources, marketing and distribution networks, purchasing collaborations, economies of scale in the production, research and development (R\&D) or other activities for revenue enhancement purposes. Static synergies are particularly important in industries with increased competitive pressures, excess capacity and falling prices, such as in the automotive industry. Dynamic synergies use complementary resources and skills to improve the firm's innovatory capability with long-term positive effects on its sales, market share and profits. Dynamic synergies are crucial in industries which are innovation-driven and experience fast technological change, such as in the information technology and pharmaceutical sectors (Ghemawat and Costa, 1993).

The agency motive holds that cross-border M\&As occur because they increase the acquirer's value for its shareholders. According to UNCTAD (2018), cross-border M\&As also provide the easiest and fastest access to new markets and expand the acquiring firm's market. With the acceleration of globalisation, fast changing of the global environment, greater competition and shorter product life cycle, there are increasing pressures on the firms to respond quickly to opportunities in order to gain the competitive advantage. Furthermore, merger or acquisition with a firm in a new market with an established distribution system and local market knowhow is far more preferable to developing a new local distribution and marketing network. Boateng et al. (2008) strengthens this point by claiming that emerging economies' firms constantly search for the market share and power in an increasingly competitive environment. 


\section{Pham, H. L. - Marek, P.: A Review of the European Union Countries on Cross-border Mergers}

and Acquisitions Market.

Diversification is another reason for cross-border M\&As as a business-expansion strategy (Seth 1990, Shleifer et al., 1992). Boateng et al. (2008) suggest that through international acquisitions, firms can reduce their costs and risks and increase their value by entering into new foreign markets. They examined the motives for cross-border M\&As acquisitions and found diversification to be the most important motive for Chinese firms' acquisitions abroad. While investigating acquisition activities, Bhagat et al. (2011) suggest that countries can gain the acquiring firms' diversification benefits when the cash flows of the acquiring and the target firm are less correlated, the combined company's cash flow has a smaller variance and a lower cost of debt. Furthermore, reduced operational and financial risks through geographical market diversification are the source of crossborder acquisitions' value as opposed to purely domestic acquisitions (Seth, 1990). It therefore follows that firms may engage in cross-border M\&As primarily due to the wish to reduce their risk through diversification. Schimizu et al. (2004) suggest that cross-border M\&As may be motivated by internalisation of the acquirer's various intangible assets and, conversely, the acquirer can also use the target's intangible assets through reverse internalisation. Acquiring or merging is sometimes the only way to get hold of strategic assets, such as brand names, R\&D or know-how, patents, local permits and licences, or supplier and/or distribution networks, because elsewhere these are not readily available and take time to develop. The volume of M\&As has been recently increasing, especially in the information technology services, natural resources, and the financial sector. According to the UNCTAD and World Investment Report reviews, around 80 per cent of FDI in developed countries have taken place in the form of cross-border M\&As.

In terms of their value, cross-border M\&As can surpass investments into the greenfields. As supported by Mody and Negishi (2000), cross-border M\&As also provide through restructuring immediate liquidity, prevent asset losses and enhance resource allocation, especially for the distressed firms in developing countries. Gregory and McCorriston (2005) state that cross-border M\&As result in a significant wealth creation to the bidders' shareholders. Others studies have also shown that acquisitions could bring wealth gains to distressed firms (Harris and Ravenscraft, 1991; Hotchkiss and Mooradian, 1998). Calderon et al. (2004) argue that M\&As are no longer an economic investment phenomenon, but a mainstream economic activity instead.

\section{Cross-border M\&A Performance Measurement}

M\&A performance can be considered as a measure of the M\&As' overall effectiveness. In Figure 4, we present the framework for cross-border M\&A performance measures adopted in advanced economies based on our own research. (For more, see Zollo et al., 2008, Meglio et al., 2011). 
Fig. 4 Cross-border M\&A Performance

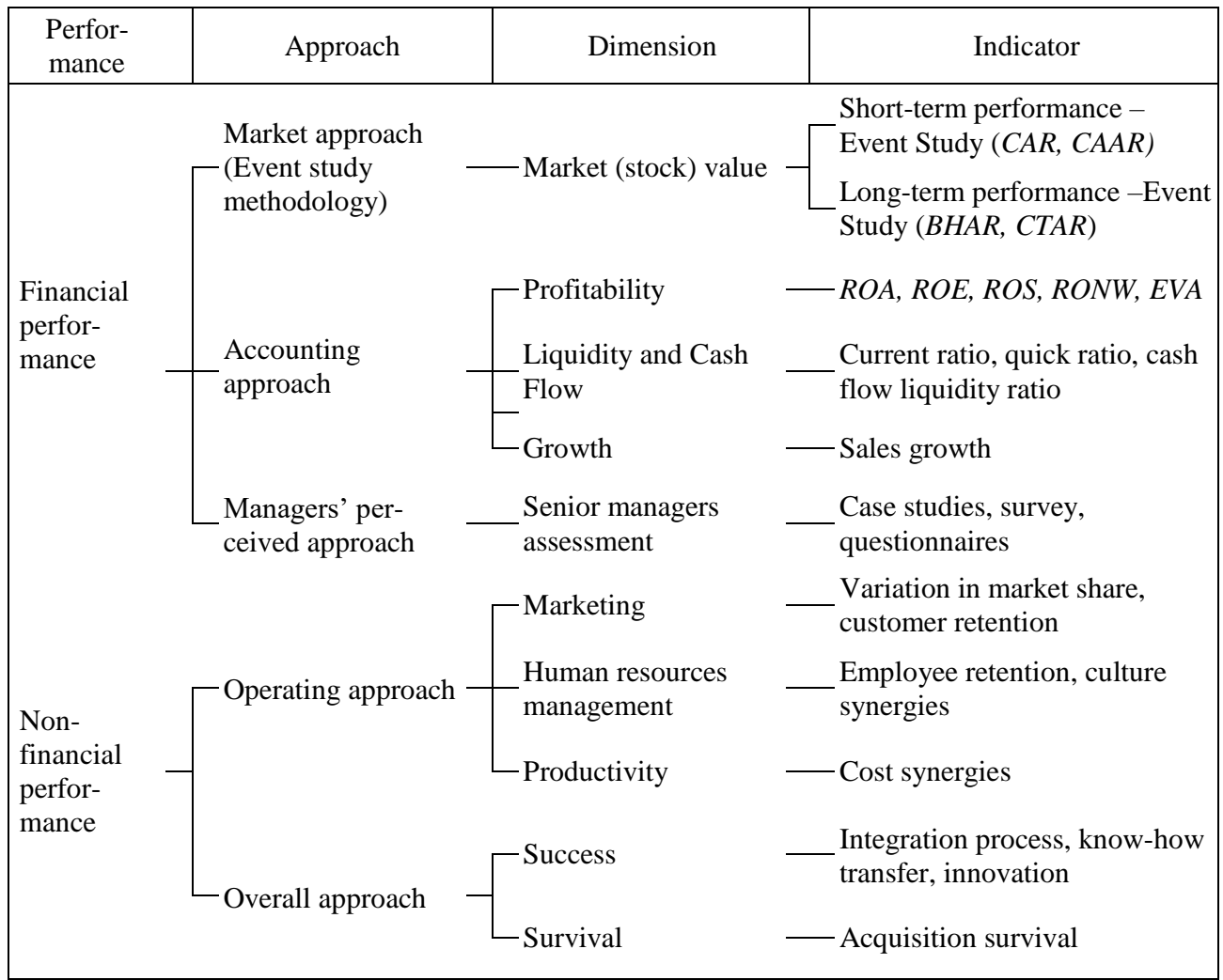

Source: Own construction (see Pham, 2014).

The scheme is divided in two performance groups indicative of how the crossborder M\&A performance is measured in terms of its financial or non-financial nature. The measures listed in Figure 4 are those we found in the cross-border M\&A performance literature. The financial group consists of the market, accounting, and managers' perceived approach of performance. The market approach is divided into two different subgroups: the company's market value at the time of the deal's announcement and at the time of its closing. The market value is generally measured in terms of CAR (Cumulative Abnormal Returns), CAAR (Cumulative Average Abnormal Returns), BHAR (Buy and Hold Abnormal Returns) or CTAR (Calendar-time Abnormal Returns). Market performance measures are only available for public companies. Accounting measures rely on financial information from the companies' accounting records and usually are expressed as values, ratios, or percentages. Accounting measures are split into three different dimensions. The first dimension is represented by profits, measured in particular by Return on Assets (ROA), Return on Equity 
Pham, H. L. - Marek, P.: A Review of the European Union Countries on Cross-border Mergers and Acquisitions Market.

(ROE), Return on Sales (ROS), Return on Net Worth (RONW) or EVA (Economic Value Added). The second dimension comprises growth, measured by sales growth. The third dimension includes liquidity and the Cash Flow Liquidity Ratio, measured e.g. by the current or quick ratio. Managers' perceived approach contains assessments using e.g. case studies, surveys and questionnaires.

The non-financial domain comprises operating and overall approaches. Measures of the operating approach reflect three dimensions: marketing (measured by the market share), human resources (employee retention, culture synergies) and productivity (cost synergies) The overall performance measures reflect two dimensions: success (measured by the degree of attainment and the number of patents or patent frequency) and survival (divestiture within the chosen time interval). From the Figure 4 we can see that cross-border M\&A performance is an ambiguous construct which lacks any broader consensus on its measurement. In other words, we can conclude that the scheme as presented in the figure above indicates that M\&A researchers measure the cross-border M\&A performance in different modes, using a wide range of indicators, broad or narrow definitions, different time horizons and units of analysis.

\section{Conclusion}

Cross-border M\&As have grew into a significant and crucial strategy, adopted by corporations in multiple regions across the world. While cross-border and domestic M\&As have a lot of characteristics in common, concurrently they also report unique and important differences. However, given their increasing popularity and importance, our intent has been to review and analyse the existing research and situation of only the cross-border M\&As and to describe the adopted primary theoretical perspectives along with the major findings of the existing research.

Recently, the M\&A market once again calls for a renewed attention. In total there have been to date declared six M\&A waves and further waves may be expected in the near future. The European Union's economies continue to represent a bright spot of the global economy. The region's potential is hard to ignore, it is culturally diverse and highly populated, representing a vast potential. Despite the renewed concerns over the global economic outlook (the decline in values of cross-border M\&As in 2017), it is believed that cross-border M\&As will accelerate again in the near future, driven by supportive macro-environment and strategic factors. Even though the outlook for 2019 remains uncertain, it is believed that cross-border M\&As will lead the future economic recovery and especially cross-border M\&As in the European Union and Asia are poised to accelerate. Moreover, when the global economy is on its way to recovery, this will possibly trigger a fresh wave of cross-border M\&As. 


\section{References}

Aw, M., Chatterjee, R., 2004. The performance of UK firms acquiring large crossborder and domestic takeover targets. Applied Financial Economics 14, 337-349. DOI: $10.1080 / 0960310042000211605$.

Bhagat, S., Malhotra, S., Zhu, P. C., 2011. Emerging country cross-border acquisitions: Characteristics, acquirer returns and cross-sectional determinants. Emerging Markets Review 12, 250-271. DOI: 10.1016/j.ememar.2011.04.001.

Boateng, A., Wang, Q., Yang, T. L., 2008. Cross-border M\&As by Chinese firms: An analysis of strategic motives and performance. Thunderbird International Business Review 50, 259-270. DOI: 10.1002/tie.20203.

Calderon, C., Loayza, N., Serven, L., 2004. Greenfield Foreign Direct Investment and Mergers and Acquisitions: Feedback and Macroeconomic Effects. World Bank Policy Research Working Paper 3192. DOI: 10.1596/1813-9450-3192.

Chen, C., Findlay, C., 2003. A Review of Cross-border Mergers and Acquisitions in APEC. Asian-Pacific Economic Literature 17, 14-38. DOI: 10.1046/j.14678411.2003.00129.x.

Danbolt, J., Maciver, G., 2012. Cross-Border versus Domestic Acquisitions and the Impact on Shareholder Wealth. Journal of Business Finance and Accounting 39, 1028-1067. DOI: 10.1111/j.1468-5957.2012.02294.x.

Dunning, J. H., 2000. The eclectic paradigm as an envelope for economic and business theories of MNE activity. International Business Review 9, 163-190. DOI: 10.1016/s0969-5931(99)00035-9.

Ghemawat, P., Costa, J., 1993. The organizational tension between static and dynamic efficiency. Strategic management journal 14, 59-73. DOI: 10.1002/smj.4250141007.

Gregory, A., McCorriston, S., 2005. Foreign acquisitions by UK limited companies: Short- and Long-run performance. Journal of Empirical Finance 12, 99-125. DOI: 10.1016/j.jempfin.2003.10.003.

Gugler, K., Mueller, D. C., Weichselbaumer, M., 2012. The determinants of merger waves: An international perspective. International Journal of Industrial Organization 30, 1-15. DOI: 10.1016/j.ijindorg.2011.04.006.

Harford, J., 2005. What drives merger waves? Journal of Financial Economics 77, 529-560. DOI: 10.1016/j.jfineco.2004.05.004.

Harris, R. S., Ravenscraft, D., 1991. The role of acquisitions in foreign direct investment: Evidence from the US stock market. Journal of Finance 46, 825-844. DOI: 10.1111/j.1540-6261.1991.tb03767.x. 
Pham, H. L. - Marek, P.: A Review of the European Union Countries on Cross-border Mergers and Acquisitions Market.

Hotchkiss, S. E., Mooradian, R. M., 1998. Acquisitions as a Means of Restructuring Firms in Chapter 11. Journal of Financial Intermediation 7, 240-262. DOI: 10.1006/jfin.1998.0243.

Martynova, M., Renneboog, L., 2008. A century of corporate takeovers: What have we learned and where do we stand? Journal of Banking \& Finance 32, 21482177. DOI: 10.1016/j.jbankfin.2007.12.038.

Meglio, O., Risberg, A., 2011. The (Mis)measurement of M\&A Performance. A Systematic Narrative Literature Review. Scandinavian Journal of Management 27, 418-433. DOI: 10.1016/j.scaman.2011.09.002.

Mody, A., Negishi, S., 2001. Cross-border mergers and acquisitions in East Asia: trends and implications. International Monetary Fund. Finance and Development 1. Available from: < https://www.imf.org/external/pubs/ft/fandd/2001/03/mody. htm>. [10 November 2018].

Papadakis, V. M., Thanos, I. C., 2010. Measuring the Performance of Acquisitions: An Empirical Investigation Using Multiple Criteria. British Journal of Management 21, 859-873. DOI: 10.1111/j.1467-8551.2009.00671.x.

Pham, H. L., 2014. Metody měření výkonnosti/efektivnosti přeshraničních fúzí a akvizic - rozvíjející se ekonomiky. Český finanční a účetní časopis 3, 122-131. DOI: $10.18267 /$ j.cfuc.413.

Rhodes-Kropf, M., Viswanathan, S., 2004. Market valuation and merger waves. Journal of Finance 59, 2685-2718. DOI: 10.1111/j.1540-6261.2004.00713.x.

Seth, A., 1990. Sources of value creation in acquisitions: An empirical investigation. Strategic Management Journal 11, 431-446. DOI: 10.1002/smj.4250110603.

Shimizu, K., Hitt, M. A., Vaidyanath, D., Pisano, V., 2004. Theoretical foundations of cross-border mergers and acquisitions: A review of current research and recommendations for the future. Journal of International Management 10, 307-353. DOI: 10.1016/j.intman.2004.05.005.

Shleifer, A., Vishny, R. W., 1992. Liquidation values and the debt capacity: A market equilibrium approach. Journal of Finance 47, 1343-1366. DOI: 10.1111/j.1540-6261.1992.tb04661.x.

Shleifer, A., Vishny, R. W., 2003. Stock market driven acquisitions. Journal of Financial Economics 70, 295-311. DOI: 10.1016/s0304-405x(03)00211-3.

UNCTAD, 2012. World Investment Report 2012. Towards a new generation of investment policies, Geneva, United Nations Conference on Trade and Development. Available from: <https://unctad.org/en/PublicationsLibrary/wir2012 _embargoed_en.pdf>. [23 September 2018]. 
UNCTAD, 2018a. World Investment Report 2018. Investment and new industrial policies, Geneva, United Nations Conference on Trade and Development. Available from: <https://unctad.org/en/PublicationsLibrary/wir2018_overview_ en.pdf>. [23 September 2018].

UNCTAD, 2018b. World Investment Report: Annex Tables, Value of net crossborder M\&A purchases, by region/economy of purchaser, 1990-2017, Geneva, United Nations Conference on Trade and Development. Available from: <https://unctad.org/Sections/dite_dir/docs/WIR2018/WIR18_tab06.xlsx>. [23 September 2018].

UNCTAD, 2018c. World Investment Report: Annex Tables, Value of net crossborder M\&A purchases, by region/economy of seller, 1990-2017, Geneva, United Nations Conference on Trade and Development. Available from:

<https://unctad.org/Sections/dite_dir/docs/WIR2018/WIR18_tab05.xlsx>. [23 September 2018].

Zollo, M., Meier, D., 2008. What is M\&A Performance? Academy of Management Perspectives 22, 55-77. DOI: 10.5465/amp.2008.34587995. 